\title{
Determinants of consumer behavior in aesthetic medicine services
}

\author{
Determinanty zachowań konsumentów korzystających \\ z usług medycyny estetycznej
}

\author{
mgr Anna Gogołek \\ Uniwersytet Ekonomiczny w Poznaniu, Wydział Towaroznawstwa, Katedra Marketingu Produktu \\ ORCID: 0000-0002-8932-0021 \\ e-mail: anna.gogolek@ue.poznan.pl
}

\begin{abstract}
Aesthetic medicine is constantly developing branch of medical science in Poland. More and more women but also men are still looking for the best treatments to make themselves young and attractive. Most of the treatments does not exclude of a daily life that is why aesthetic medicine is so gaining popularity. The dynamic development with new technologies and ever-smaller pain during treatments results in an increasing interest of the potential patients/consumer. Thanks to that, there are more and more institutions dealing with this field of medicine in Poland. In this article below the author presented the results of the marketing study, which was to determine the determinants of consumer behavior in aesthetic medicine services. In particular, the focus was on the age in which patients for the first time used aesthetic medical treatment, determinants influencing decisions of uses aesthetic medical treatment, criteria for selecting the aesthetic medicine clinic, determinants influencing decisions of uses aesthetic medicine treatment and the most popular services.
\end{abstract}

\section{Keywords}

aesthetic medicine, consumer behavior, patient, anti-aging

\begin{abstract}
Medycyna estetyczna to stale rozwijająca się dziedzina medycyny w Polsce. Coraz więcej zarówno kobiet, jak i mężczyzn poszukuje najlepszych zabiegów, by utrzymać młodą i atrakcyjną kondycję skóry i ciała. Większość usług medycyny estetycznej nie wymaga czasu rekonwalescencji, dlatego zyskuje coraz większą popularność. Dynamicznie rozwijające się nowe technologie oraz tworzenie procedur o jak najmniejszej bolesności znacznie zwiększają zainteresowanie potencjalnych konsumentów/ pacjentów. Dzięki temu wzrasta liczba nowo powstałych placówek zajmujących się właśnie tą stosunkowo nową dziedziną medycyny. W niniejszym artykule, autor przedstawił determinanty zachowań konsumentów na rynku usług medycyny estetycznej. Szczególną uwagę skupiono na wieku pacjentów/konsumentów podczas pierwszej wizyty w klinice medycyny estetycznej, na określeniu czynników, jakimi kierował się pacjent/konsument podczas wyboru placówki medycyny estetycznej oraz samej usługi, a także na najbardziej popularnych zabiegach.
\end{abstract}

Slowa kluczowe

medycyna estetyczna, zachowania konsumentów, pacjent, anti-aging

JEL: M310, M300

Str. $37-43$

\section{References}

Ankiel, M. \& Kuczynska, A. (2017). Wyznaczniki satysfakcji klientów korzystających z usług medycyny estetycznej. Studia Ekonomiczne. Zeszyty Naukowe Uniwersytetu Ekonomicznego w Katowicach, (330).

Cutan, J. (2009). The need for evidence-based aesthetic dermatology practice. Journal of Cutaneous and Aesthetic Surgery, 2(2), 65-71. https://doi.org/10.4103/0974-2077.58518 
Donejko, M. (2017). Atrakcyjność. In A. Przylipiak (ed.), Medycyna Estetyczna. Podręcznik dla studentów kosmetologii (1-5). Warszawa: Wydawnictwo Lekarskie PZWL.

Dydlewska-Grzelkowska, J. (1999). Kosmetyka stosowana. Warszawa: WSiP.

Galęba, A. (2011). Ocena jakości życia pacjentów przed i po wybranych zabiegach z zakresu medycyny estetycznej. (Unpublished doctoral dissertation). Uniwersytet Medyczny im. Karola Marcinkowskiego w Poznaniu.

Goldberg, J. (2009). Lasery i Światlo. Wrocław: Elsevier Urban\& Partner.

Hodgkinson, D. (2005). Identifying the body-dysmorphic patient in aesthetic surgery. Aesthetic Plastic Surgery, 29(6), 503-509. https://doi.org/10.1007/s00266-005-5033-6

Jurkowska, S. (2001). Produkty kosmetyczne. Dąbrowa Górnicza: Ośrodek Informacyjno-Badawczy Ekoprzem.

Marcela Betancure, D., Montoya Castaneda, K., \& Tavera-Mesías, J. F. (2017). Correlation study of the factors that influences in the recommendation and loyalty of patients of aesthetic medicine Medellin Colombia, 2014. Cuadernos de Administración, 33(58). https://doi.org/10.25100/cdea.v33i58.4527

O'Neill, J. (2017). Taking a medical history. Retrived from http://www.aestheticjournal.com

Przylipiak, A. \& Lubowicka, E. (2017). Psychologiczne aspekty w medycynie estetycznej. In A. Przylipiak (ed.) Medycyna Estetyczna. Podręcznik dla studentów kosmetologii (7-18). Warszawa: Wydawnictwo Lekarskie PZWL.

Redaelli, A. \& Ignaciuk, A. (2010). Medycyna estetyczna. Warszawa: Wydawnictwo Medycyny Estetycznej.

Religioni, U. \& Religioni, M. (2015). Medical tourism trends in Poland. Medical and Biological Sciences, $29(2), 63-67$. https://doi.org/10.12775/MBS.2015.020

Śpiewak, R. (2013). Ocena skuteczności zabiegów w estetologii medycznej i kosmetologii: jak zmierzyć obiektywnie wrażenia subiektywne? Academy od Aesthetic and Anti-Aging Medicine, (4), 3-12. Retrived from http://www. radoslawspiewak.net/2013-10.pdf

Wasiluk, M. (2016). Medycyna estetyczna bez tajemnic. Warszawa: Wydawnictwo Lekarskie PZWL.

Venkat, K., Schamid, B., Summer, E., \& Bentz, M. (2011). Establishing a multidisciplinary academic cosmetic center. Plastic Surgery and Reconstructive Surgery, 128(6), 741-746. https://doi.org/10.1097/PRS.0b013e318222133a 